\title{
Factors Affecting Profit Distribution Management of General Islamic Banks In Indonesia
}

\author{
Nur Afni Yunita ${ }^{1}$, Yunina ${ }^{1}$, Sri Mulyati ${ }^{1}$, Dy Ilham Satria ${ }^{1}$, Muammar Khaddafi ${ }^{1}$, \\ Wahyuddin Albra ${ }^{2}$ \\ \{nurafni.yunita@unimal.ac.id\} \\ ${ }^{1}$ Departement of Accounting, Universitas Malikussaleh, Aceh, Indonesia \\ ${ }^{2}$ Department of Management, Universitas Malikussaleh, Aceh, Indonesia
}

\begin{abstract}
Operational of Islamic Banking always prioritize the principles of Muamalat (transaction or dealing), fairness, and togetherness between the bank and the customer. These principles are the foundation resulting in Islamic banks outperforms other conventional banks. The fairness principle is also used in dividing the profit including Profit Distribution Management (PDM). PDM is the profit distribution based on the ratio agreement between the Islamic bank and depositor. The fluctuation movement of PDM is influenced by several factors including internal and external factors. Some internal factors of Islamic banks influencing PDM including are Capital Adequacy, Effectiveness of Depositors Funds, Asset Composition, Deposits, Productive Assets Management, and Inflation Rate. This study aims to investigate and analyse the factors affecting PDM. This study was conducted at 11 general Islamic bank registered in Indonesia in the period of 2012 to 2016. The results show that there are four factors significantly influencing PDM, namely: Capital Adequacy, Effectiveness of Depositors Funds, Asset Composition and Deposits. Two other factors, namely: Productive Assets Management and Rate of Inflation have no significant influence on PDM.
\end{abstract}

Keywords: Profit Distribution Management (PDM), Capital Adequacy, Effectiveness of Depositors Funds, Asset Composition, Deposits, Productive Assets Management, Rate of Inflation

\section{INTRODUCTION}

It puts a greater emphasis on the principles of muamalat (transaction or dealing), fairness and togetherness, in both obtaining profit and overcoming the risk. The Islamic Banking than conventional banking are more interest free banking based from [1]. Recent studies almost investors choose Islamic Banking for religious reasons rather, even though the depositors may make a comparison between rates of profits from one Islamic Bank to another.

In the process of both collecting and distributing the fund, GIB implements the profit system using revenue and profit sharing as well as risk sharing, its mean the Profit Distribution Management (PDM). Profit Distribution Management is its profit sharing to 
smoothing their profit, such as to maintain higher rate of return [2],Profit Distribution Management was in process of both collecting and distributing the fund, GIB implements the profit system using revenue and profit sharing as well as risk sharing [3]. According to [4], Profit Distribution Management based on effect differential timing of investment, debt, capping the profits with an early buy-out option the fund, and Guarantee of compensation for loss of capital. The result of this statement that The Distribution Management influenced by the fund of investors are called The Third Parties Fund.

The movement of fund gathered from the society in GIB in Indonesia is significantly growing. The Third Parties Fund increases from the gyro product, saving and deposit. The latest data from [5] is presented in Table 1

Table 1. The Third Parties Fund General Islamic Banks in Indonesia

\begin{tabular}{lllll}
\hline The Third Parties Fund & Giro & Saving & Deposit & Total \\
\hline The Third Parties Fund (Rp Trillion) & 19.65 & 64.73 & 122.02 & 206,41 \\
Growth (yoy) & $32.15 \%$ & $22.76 \%$ & $13.73 \%$ & $18,02 \%$ \\
\hline
\end{tabular}

The growth of third parties fund in GIB presented in Table 1.1 indicates that the society trust on the Islamic principles has been fully conducted in the bank operational. The growth of third parties' fund is also the biggest contributor to improve the performance of GIB. The Third Parties Fund is also one of the indicator was measure the growth of performance together with Total Asset Bank and Landing Financing. The performance movement of third parties' fund GIB is illustrated in table 2 .

Table 2. Indicators Performance General Islamic Banks in Indonesia

\begin{tabular}{|c|c|c|c|c|c|}
\hline Indicators & 2012 & 2013 & 2014 & 2015 & 2016 \\
\hline Asset (Rp. Triliun) & 147,58 & 180,36 & 204,96 & 213,42 & 254,184 \\
\hline Growth (yoy) & $26.21 \%$ & $22.21 \%$ & $13.64 \%$ & $4.13 \%$ & $19.10 \%$ \\
\hline $\begin{array}{l}\text { The Third Parties Fund } \\
\text { (Rp Trillion) }\end{array}$ & 117,81 & 143,17 & 170,72 & 174,89 & 206,407 \\
\hline Growth (yoy) & $22.03 \%$ & $21.52 \%$ & $19.24 \%$ & $2.44 \%$ & $18.02 \%$ \\
\hline $\begin{array}{l}\text { Landing Financing (Rp. } \\
\text { Triliun) }\end{array}$ & 112,39 & 137,26 & 147,94 & 153,968 & 177,48 \\
\hline Growth (yoy) & $34.28 \%$ & $22.13 \%$ & $1.99 \%$ & $3.56 \%$ & $16.41 \%$ \\
\hline
\end{tabular}

Based on the two phenomena presented in Table 1and 2, this study is designed to further analyse the factors affecting the activity of Profit Distribution Management (PDM).

Profit distribution Management (PDM) is the profit sharing of Islamic banks to the customer based on the agreed ratio each month. PDM is managed based on the product chosen by the customers and its rate of ratio. PDM is also known as the distribution of business profit or the distribution of income and the distribution of profit sharing.

\section{LITERATURE REVIEW}

Bank Indonesia defined profit-sharing distribution as the profit-sharing of Islamic banks to deposit customers based on the agreed ratio every month.[6] stated that Profit Distribution 
Management (PDM) is an activity of managers in allocating the distribution of profit-sharing of Islamic banks to their customers. Profit Distribution Management is activity conducted by managers in allocating the distribution of profit-sharing of Islamic banks to their customers every period/month agreed. The calculate the Profit Distribution Management that refers consider all revenue and expense, and provide the spread between total asset return on assets[7]. So indicator of Profit Distribution Management is:

$$
\text { PDM }=\frac{\text { Profit After Tax }}{\text { Total Asset }} \times 100
$$

Profit Distribution Management influenced by several factor, one of them is a Capital Adequacy. Capital Adequacy can be interpreted as bank ability to cover the loss caused which is supported by the availability of fixed asset and investment[6]. The indicator used to measure the Capital Adequacy is CAR (Capital Adequacy Ratio).

$$
\text { CAR }=\frac{\text { Capital }}{\text { Total of ATMR }} \times 100
$$

The greater this ratio means the healthier of the bank to conduct their performance. The high CAR enables banks to overcome the risks resulting in the managers being braver in organizing the profit distributionmanagement (PDM) referring to the interest rates as the bank is a safe condition. In relation to the stakeholder theory, Islamic banks will increase the PDM referring to the interest rates to satisfy the depositors. Its similarity result from [8]is a positive relationship between capital adequacy and the level of profit and sharing the return.

H1: CAR has effect to Profit Distribution Managment

The second factor is Effectiveness of Depositors Fund. According to[9], Effectiveness of Depositors Fund witch proxy by Financial to Deposit Ratio is measurement the bank ability to return withdrawls made my investors and by relying on financing provides as sourceliquidity. Effectiveness ofDepositorsFunds can be measured by financing todeposit ratio (FDR) [2]The indicator of FDR is:

$$
\text { FDR }=\frac{\text { Total Financing }}{\text { Total The Third Parties Fund }} \times 100
$$

According to[10], Effectiveness of Depositors Fund is reflection of intemediary function between the investor as the owner of the third parties fund and the bank. On in other words as a costumer realitoinship. Thereofer the bank will increase Profit Distribution Management on . The high FDR indicates that the the refers to the level of profit sharing. This will automatically increase the rate of profit sharing.

H2: FDR has effect to Profit Distribution Management

The third factor is AssetComposition. Asset Composition can be said also as a proposition of non-invesment financing and is flat. The financing is based on the initial agreement at the time of the contract. So that price and profits are recognized at initial agreement without any change of interest rate durings the financing [8]. The amount of Asset Composition determines the amount of return thatt will be returned mitmach so that Islamic Banking can detemine the amoun of Profit Distribution Management. Especially the exposure financing with fixed interest rate, may influence the extent the banks manage the profit distribution to the 
depositors. According to [2], AssetComposition can be measured using the ratio of LoanAssetto Total Asset (LATA). LATA is

$$
\text { LATA }=\frac{\text { Loan Asset }}{\text { Total Asset }} \times 100
$$

LATA determines the level of which the Islamic bank conduct profit distribution management to return mismatch in the market condition when interest rate changes [10]. Therefore, the higher ratio corresponds to the higher rate of PDM.

\section{H3: $\quad$ LATA has effect to Profit Distribution Management}

The fourth factor is Deposit. Deposit is the variables describing the level of bank dependency towards depositors. Consider that[10], Deposit explains how much the banks attachment to Third Parties Fund. If insufficient fund accur then the bank can not perform its functions with maximum even not work at all . Deposits is measured based on the percentage of depositors' fund of the total asset. [2] argued that Islamic bank holding smaller proportion of third party fund than the shareholders tends to manage PDM.

$$
\text { Deposits }=\frac{\text { The Third Parties Fund }}{\text { Total Asset }} \times 100
$$

In the stakeholder theory the bank will handle the depositr, thus maximing the level of Profit Distribution Mangement. With a high rate Profit Distribution will be impact to increase the external funding. Another that a high proposition of funds was effect possibilityof withdrawal funds by depositors, [11].

H4: Deposit has effect to Profit Distribution Management

The fifth factor is Productive Asset Management. Productive Asset Management Productive Assets Management shows bank ability in producing income based on the performance of Islamic banks in channeling the financing, considered that bank operational income highly depends on the difference of spread and the financing channeled[1]. Productive Asset Manegement too explained the capability in generating revenue by performance of the Islamic Banking in distribution the financing[12]. Productive Assets Management can be proxied by Net Interest Margin (NIM). It be measure that

$$
\text { NIM }=\frac{\text { Net Interest }}{\text { Net Revenue }} \times 100
$$

Based on result research by[10];[13], that argued that the failure in considering the spread between the interest rate and financing margin will have an impact on the loss of profit margin, the loss of better quality of debtors, failure in calculating the loss of non-performing loan and the decrease of the profit-sharing quality, concluding that Productive Asset Management gives effecting on Profit Distribution Management.

H5: NIM has effect to Profit Distribution Management

The last factor is Rate of Inflation. Rate of Inflation is the continuous increase of general price level in economy. The rate of inflation year by year in Indonesia can be observed from the percentage of the change of consumer price index (IHK). Based on result [6] that high 
inflation rate cause costs to increase and less profitable productive activities. According to[12], the increase inflation rate may effect to reduce the corporate earnings, including Islamic Banking, so its consequently to reduce the Profit Distribution Management. Itssimilary that result by [10], Indonesia's macroeconomic condition has not been able to provide a positive bussiness climate for Islamic Banking industry. If its associated with stakeholder theory, the hight rate of inflation resulted in the level of Profit Distribution of islamic banks tend to decrease. While indonesia's economic growth is not high enough and strong enough to drive the real sector that becomes the source of revenue for the result of Islamic Banking. The rate of inflation year by year in Indonesia can be observed from the percentage of the change of consumer price index (IHK).

$$
I H K=\frac{I H K_{t}-I H K_{t-1}}{I H K_{t-1}}
$$

H6: Rate of Inflation has effect toProfit Distribution Management.

\section{METHODS}

This study used statistics model proposed bymultiple regression analysis using Ordinary LeastSquare (OLS). The multiple regression analysis was conducted to examine the accuracy of the relationships between PDM (dependent variable) and Capital Adequacy,Effectiveness ofDepositors Funds, Assets Composition,Deposits,Productive Assets Management,and Rate of Inflation as the independent variables. And than the resarch used descriptive analyze and analyze hypothesis test.Hypothesis testing is done by accepted if the significancy value less than 0.05 or $5 \%$.

The formula of regreession analysis is:

$$
\mathrm{Y}=\beta_{1} \mathrm{CAR}+\beta_{2} \mathrm{FDR}+\beta_{3} \mathrm{LATA}+\beta_{4} \mathrm{DEPOSIT}+\beta_{5} \mathrm{NIM}+\beta_{6} \mathrm{IHK}
$$

The sample in this study was 11 GIB in Indonesia from the period of 2012 to 2016 . The detailed information is presented in table 3

Table 3. Sample of Research

\begin{tabular}{ll}
\hline No & The Name of GIB \\
\hline 1 & PT. Bank Muamalat Indonesia \\
2 & PT. Bank Victoria Syariah \\
3 & PT. Bank BRISyariah \\
4 & PT. Bank Jabar Banten Syariah \\
5 & PT. Bank BNI Syariah \\
6 & PT. Bank Syariah Mandiri \\
7 & PT. Bank Mega Syariah \\
8 & PT. Bank Panin Syariah \\
9 & PT. Bank Syariah Bukopin \\
10 & PT. BCA Syariah \\
11 & PT. Maybank Syariah Indonesia \\
\hline
\end{tabular}




\section{RESULT \& DISCUSSION}

Descriptive statistics provides a brief overview of Islamic banks in the table 4.1. The PDM variable has a minimum of $-1,7401$ for Bank Victoria Syariah in 2015. While the maximum of 2,2826 is Bank Maybank Syariah Indonesia in 2014. The means of PDM is 0.9520 with standard devation of 0.77353 . It indicates the data have distribution normal. The other data have be seen in the Table 4Descriptive Statistic

The model of analyz regression of the data is (based on table 5):

$\mathrm{Y}=0,487+0,45 \mathrm{CAR}+0,577 \mathrm{FDR}-0,366 \mathrm{LATA}+0,381 \mathrm{DEPOSIT}+0,520 \mathrm{NIM}+0,547 \mathrm{IHK}$

Based on the above regression formula can be concluded that each independent variable has a positive relationship to dependent. It means every increase of independent variable causes the increase of dependent variable.

Table 4. Descriptive Statistic

\begin{tabular}{lccccc}
\hline & N & Minimum & Maximum & Mean & Std. Deviation \\
\hline PDM & 54 & $-1,7401$ & 2,2826 &, 638443 &, 7735348 \\
CAR & 54 &,- 1825 &, 5941 &, 200430 &, 1199760 \\
FDR & 54 &, 7277 & 1,5777 &, 952281 &, 1507153 \\
LATA & 54 &, 0407 & 1,0818 &, 558889 &, 2446383 \\
DEPOSIT & 54 &, 0060 & 1,2525 &, 768930 &, 2155089 \\
NIM & 54 &,- 2784 &, 1394 &, 044459 &, 0510223 \\
IHK & 54 &,- 5993 &, 9488 &, 075567 &, 5108780 \\
Valid N (listwise) & 54 & & & & \\
\hline
\end{tabular}

Table 5. Coefficients

\begin{tabular}{|c|c|c|c|c|c|c|}
\hline \multirow[t]{3}{*}{ Model } & \multirow{2}{*}{\multicolumn{2}{|c|}{$\begin{array}{l}\text { Unstandardized } \\
\text { Coefficient }\end{array}$}} & Standardized & \multirow{3}{*}{ Sig. } & \multirow[t]{3}{*}{$\mathrm{R}$} & \multirow{3}{*}{$\begin{array}{c}\mathrm{R} \\
\text { Square }\end{array}$} \\
\hline & & & Coefficients & & & \\
\hline & B & Std. Error & Beta & & & \\
\hline (Constant) & .487 & .156 & & .675 & \multirow{7}{*}{$.6514^{\mathrm{a}}$} & \multirow{7}{*}{.8070} \\
\hline CAR & .405 & .322 & .063 & .0361 & & \\
\hline FDR & .577 & .015 & .112 & .0372 & & \\
\hline LATA & .366 & .462 & -.116 & .0433 & & \\
\hline DEPOSIT & .381 & .604 & -.106 & .0499 & & \\
\hline NIM & .520 & .472 & -.034 & .0834 & & \\
\hline IHK & .547 & .227 & .361 & .0200 & & \\
\hline
\end{tabular}

For the analyse Hypothesis the result is In the Capital Adequacy that has the sig value is 0.0361 or has a sig level more than $0.05(0.0361<0.05)$.

CAR have the positive effect to Profit Distribution Management, with coefficient is 0.450 or $45 \%$. CAR be effect to Profit Distribution Management (H1 is accepted). The higher level of Capital Adequacy of a Islamic Banking observed from the Capital Adequacy Ratio (CAR) will encourage increased Profit Distribution Management.

The test results are in line with previous research conducted by[14];[9];[10]; [15]. But not linear with result by[6]that CAR not effecting to Profit Distribution Management and [9] with car have a negative effect 
Effectiveness of Depositors Fund with the indicator is FDR has a significance level below $0.005(0.0373<0.0500)$. It means that hypothesis $2(\mathrm{H} 2)$ is accepted. FDR be effect to Profit Distribution Management, with the coefficient is 0.577 or $57.70 \%$. Its mean FDR has positive effect to Profit Distribution Management. So the higher the FDR of a bank can be a benchmark to increase Profit Distribution Management. Its result same with previous research by[10];[15];[6]; and[11], but difference with previous research by[13]

Asset Composition (LATA), Deposit (Deposit), and Inflation Rate (IHK) variable have significance level with sig. value below 0.005 . that each value 0.0433 for LATA, 0.0499 fot Deposit and 0.0200 for IHK. Its result same with previous research by [8] and [12] But its not similarity with research[10]; and[11].

Assets Management with the indicator is NIM. NIM Variable had a different result. NIM has the sig.value is 0.0761 or has a sig level more than $0.05(0.0834>0.05)$. its mean to rejected hypothesis. NIM not be effect to Profit Distribution Management (H5 was rejected). This research is in line with[11].

The significance test of the research model has value of $\mathrm{R} 2=0.8070$ which means that $80.70 \%$ of independent variable (CAR, FDR, LATA, DEPOSIT, NIM and IHK) can explain the effect to dependent variable (Profit Distribution Management).

\section{CONCLUSION}

Based on the analysis results, it can be concluded that four factors positively influence Profit Distribution Management at General Islamic Bank in Indonesia, namely: Capital adequacy (CAR), Effectiveness of depositors' funds (FDR), Asset Composition (LATA),Deposit, and Rate of Inflation (IHK), while is the Assets Management (NIM) have no impact on the PDM.

\section{REFERENCES}

[1] A. Yulianto, "The Internal Factors of Indonesian Sharia Banking to Predict The Mudharabah Deposits," Rev. Integr. Bus. Econ. Res., vol. 5, no. 1, pp. 210-218, 2016.

[2] S. Farook, M. K. Hassan, and G. Clinch, "Profit distribution management by Islamic banks: An empirical investigation," Q. Rev. Econ. Financ., vol. 52, no. 3, pp. 333 347, 2012.

[3] M. Yahya and D. E. Y. Agunggunanto, "Perbbankan Syariah Dalam Ekonomi Syariah," Teor. Bagi Has. (Profit Loss Sharing) Dan Perbbankan Syariah Dalam Ekon. Syariah, pp. 65-73, 2011.

[4] M. Jaaskelainen, M. Maula, and G. Murray, "Profit distribution and compensation structures in publicly and privately funded hybrid venture capital funds," Res. Policy, vol. 36, no. 7, pp. 913-929, 2007.

[5] 2016 Otoritas Jasa keuangan, Laporan Perkembangan Keuangan Syariah 2016. 2016.

[6] M. N. S. Rachman, "Analysis of Factors Affecting Profit Distribution Management At Islamic," 2017, no. August.

[7] N. S. M. S. Noor, "An Emperical Analaysis Of Profit Distribution MNgment Decisions In Malaysian Islamic Banks,” 2006, vol. 2013, no. December, pp. 1-22.

[8] G. P. M. Mulyo, "Determinan Profit Distribution Management Bank Syariah Di 
Indonesia Periode 2008-2011," vol. 1, no. September, 2013.

[9] H. Hasbi and T. Haruman, "Banking: According to Islamic Sharia concepts and its performance in Indonesia," Int. Rev. Bus. Res. Pap., vol. 7, no. 1, pp. 60-76, 2011.

[10] S. B. Kartika, "Analisis Faktor-Faktor Yang Mempengaruhi Profit Distribution Management :," DIPONEGORO J. Account., vol. Volume 1, pp. 1-15, 2012.

[11] V. Wafaretta, Rosidi, and A. F. Rahman, "The Impact of Banks' Characteristics on Profit Distribution Management of Islamic Banks," Procedia - Soc. Behav. Sci., vol. 219, pp. 769-776, 2016.

[12] R. Ernayani, R. Robiyanto, and S. Sudjinan, "Factors influencing profit distribution management of sharia commercial banks in Indonesia," vol. 20, no. 2, pp. 187-192, 2017.

[13] T. Rifadil and S. Muniruddin, "Analisis Faktor-Faktor Yang Mempengaruhi Profit Distribution Management Pada Bank Umum Syariah Tahun 2012-2015," J. Ilm. Mhs. Ekon. Akunt., vol. 2, no. 3, pp. 140-153, 2017.

[14] H. A. Buchory, "Analysis of the effect of capital, net interest margin , credit risk and profitability in the implementation of banking intermediation," Eoropean J. Bus. Manag., vol. 4, no. 1 June 2014, pp. 20-32, 2014.

[15] G. P. Mulyo and S. Mutmainah, "Faktor-Faktor Yang Mempengaruhi Profit Distribution Management Pada Bank Syariah Di Indonesia Periode 2008-2011," SNA XV Banjarmasin, no. 2005, pp. 1-28, 2011. 